\title{
The conundrums of formal and informal meritocracy: dealing with gender segregation in the academy
}

\author{
Stina Powell ${ }^{1}$ (D) $\cdot$ Seema Arora-Jonsson ${ }^{2}$
}

Accepted: 3 May 2021 / Published online: 28 May 2021

(C) The Author(s) 2021

\begin{abstract}
Despite the academy's commitment to the idea of meritocratic and fair principles in recruitments, promotions, student admissions and progress, gender segregation and gender inequalities continue to trouble universities worldwide. Through case-studies of two education programs at a Swedish university, we investigate how processes of formal merit, both formal (required for admission such as high grades) and what we identify as informal merit (needing to act in particular ways once admitted) work to obviate or reproduce gender-segregation. We analyze how everyday gendering processes in the classroom play a central role in what gets constructed as merit. Changing notions of merit during the period of study can hamper possibilities for ending gender segregation in $\mathrm{HE}$ or open up for ways to circumvent it. We show that a complex and ongoing construction of informal merit can restrain students from minority groups (in relation to gender, but also ethnic background, socioeconomic position, or sexuality) to enter, and importantly, remain in the program. At the same time, new ways of addressing the subject itself provides potential openings. We argue that in order to achieve gender balance at universities, it is urgent to understand how informal and formal merit interplay once students have joined the university and importantly also when they have made the leap and broken with gender segregated education choices.
\end{abstract}

Keywords Merit $\cdot$ Gender segregation $\cdot$ Meritocracy $\cdot$ Gender equality $\cdot$ Academia

Seema Arora-Jonsson

Stina.Powell@slu.se

Stina Powell

Stina.Powell@slu.se

1 Division of Environmental Communication, Department of Urban and Rural Development, Swedish University of Agricultural Sciences, Uppsala, Sweden

2 Division for Rural Development, Department of Urban and Rural Development, Swedish University of Agricultural Sciences, Uppsala, Sweden 
Inequalities and gender-segregation within the academy are causing concern. Marginalization on the basis of sex, race, ethnicity, and class have been shown to persist and universities across the world have launched remedial programs. The \#metoo movement that gathered steam in 2017 brought to a head questions of sexual harassment and gendered inequalities in the academy. In Europe, structural inequalities, as for example, the skewed number of men and women in various disciplines, are most evident in natural science disciplines where women are underrepresented ${ }^{1}$ despite decades of research that has made it clear that intellectual capacity is certainly not contingent on sex or ethnicity. Research indicates that segregation is largely a result of education choices that can be traced back to cultural expectations, socialization, and social control that appear to be highly resistant to change (Barone \& Ortiz, 2011; SOU, 2009).

In this paper, we examine how gender-segregation may be obviated or reproduced after students enter the academy and how notions of merit are central to this. In the past, merit has been addressed primarily in studies of employment processes (van den Brink et al., 2010; Wullum-Nielsen, 2016), in relation to the intake of students in university programs (Nahai, 2013; Warikoo, 2016), and in research funding processes (Sandström \& Wold, 2010; Wennerås \& Wold, 1997). We develop an unconventional understanding of merit. While we adopt the conventional understanding of merit (based on high grades and hard work) as the basis on which students are accepted into educational programs, we argue that in order to understand long-term gender-segregation, we also need to focus on what we argue is "informal merit" within programs, that is, the ongoing construction of what it takes to be a suitable student during the course of studies.

In studies of two educational programs at a university in Sweden, we examine what is considered to be formally meritorious to be admitted, but once having gained admission, how that merit is tempered by needing to act in particular ways - an informal understanding of merit. We investigate what these different understandings of merit imply for being able to retain students from different social groups in the programs and bring attention to how the notion of informal merit is contingent on the professional/organizational and the larger societal structures in which the universities are positioned. Finally, we argue that merit needs to be understood as dynamic and processual and we need to understand how formal and informal merit overlap and affect the likelihood of being able to achieve gender-balance in universities.

Our analysis rests on two cases of gender-segregation within a single, primarily natural sciences university - one, a forestry program with a preponderance of men and the other, a veterinary program with primarily women. We examine how the question of merit is dealt with in these two instances as the university adopts measures to balance the number of men and women and how teachers and students try and reconcile the idea of merit with gendered institutions in and outside the university. The two cases, being skewed in such contradictory ways, provide an excellent example of what is perceived to be the same problem, an imbalance in the number of men and women — an imbalance that goes against prevailing ideas in Swedish society and policy-making about the need for an equal number of men and women in organizations to assure gender equality (Arora-Jonsson \& Ågren, 2019).

In what follows, we first turn to two intersecting literatures on meritocracy in the academy and on gender-segregation in higher education (HE) to develop our thinking on what counts for merit in $\mathrm{HE}$ and how it impacts on gender-segregation. Thereafter, we present our cases and methods and we show how gender and merit is done in the everyday life of the institution.

\footnotetext{
${ }^{1}$ Women are underrepresented in STEM, Science, Technology, Engineering, and Mathematics, https://ec. europa.eu/eurostat/web/products-eurostat-news/-/EDN-20190211-1.
} 
We end by discussing the relationship between formal and informal merit and how an understanding of these could help us work to disrupt discriminatory gender-segregation.

\section{Gender-segregation and meritocracy in academia}

We place our question on how gender-segregation is related to constructions of merit in the academy at the intersection of scholarship on gender-segregation and merit. We analyze how cultural constructions within the academy on what is meritorious during the education, affect the propensity of gender-segregation within the academy and the larger professional field.

\section{Gender segregation in higher education}

It is a common pattern worldwide that more women than men work within the humanities and social sciences, and more men in STEM, forestry, and IT (Barone, 2011). In the EU, only 32\% of the students in STEM are women and men dominate $85 \%$ of all top level positions in the field (She Figures, 2018). This has been explained in various ways. Rational choice theory suggests that women choose an education that allows them to combine work with family responsibility, while men traditionally follow masculine paths such as engineering or physics (Mastekaasa \& Smeby, 2005; Mincer \& Polachek, 1974). On the other hand, socialization theory and cultural explanations point to how girls and boys are socialized toward traditionally masculine and feminine professions, thus coloring their education choices (Dryler, 1998).

Culturalist and socialization theories as ways of explaining segregation led a Swedish governmental report (SOU, 2011:1, 187) to suggest that HE institutions can do little to affect segregation, as preferences are developed during childhood, long before joining university. Barone's (2011) study across eight European countries shows that even when men and women make less stereotypical choices in education, even within their chosen subjects, men tend to opt for technical and women for care-related aspects. Barone et al. (2019) point out that quantitative approaches usually adopted to examine gender-segregation have been limited by the lack of information on subjective beliefs about the students' chances to succeed in different fields or about their perceived profitability, which also contribute to gender differences across tertiary fields. It is to this gap on understanding the reproduction of subjective beliefs that we turn to in this paper. However, rather than the subjective beliefs formed in school, we turn to mechanisms at work within university programs that reinforce or potentially counter gendersegregation that we argue are just as important to tackle as are childhood preferences before entering university.

Building on work that shows gendering in university classrooms and in professional fields, we turn to work on how notions of the successful student (Ingram \& Allen, 2019; Nyström et al., 2018) are constructed also beyond academic results. In studies from the USA, Canada, and Sweden, Gonsalves et al. (2016) show that women in the field of physics rejected traditional femininity for a "female masculinity" to be "one of the boys" in order to negotiate the limited possible identities for them as female students in the field. ${ }^{2}$ These echo early feminists in the USA (Oreskes, 1996) who showed how, in the public eye, science was

\footnotetext{
${ }^{2}$ Conversely in a technical university in India, the few women there were referred to pejoratively by male students as "non-men," while women in other social science colleges were "women" (pers. comm. with one of the authors).
} 
associated with male heroism and objectivity and that the images that men or women were associated with, rather than what they actually did, influenced what paths they took. More recently, in the veterinary field, studies from Australia show that women often downplay feminine traits by disparaging female colleagues who they felt focus on the nurturing rather than medicinal aspects of their profession or those who worked only part-time due to family commitments (Irvine \& Vermilya, 2010).

Jackson and Dempster (2009) point to the ideal of the effortless male achiever in universities in the UK, successful academically, does not appear to put in too much hard work, but relies on natural ability. Even when women get better results, it is the male "effortless" approach to learning that is valued in the system. This hegemonic masculinity is not available to all men. Puwar (2004) shows how elite professions in the UK are occupied by male, white, upper/middle class bodies that are so naturalized in these professions that they never get questioned. As a result, certain preferences/values acquire the status of "social magic," obscuring the conditions in which the value is constructed so that fit comes to be seen as "natural," denying its cultural arbitrariness (Ingram \& Allen, 2019). This is evident in a study of nursing in Norway (Myklebust, 2020) where while students spoke of nursing as something that is "learned" in class, they nevertheless attributed the segregation in the field to women's caring natures.

That images of the discipline can take an emotional toll is evident from Ingram's work on middle-class boys in UK grammar schools (Ingram, 2011). The boys found it hard to reconcile their identity as working class with educational success, engendering in them a sense of ambivalence that made it difficult for them to operate successfully in both fields. However, as Crozier et al. (2009) point out, the gains are many, not only for the students but importantly for the universities. Universities need non-traditional students just as much as students need them.

External pressures from the professional fields also have an important impact on the organization and gender-segregation in universities. In Scandinavia, Brandth and Haugen (2005) show how despite the change from manual labor to white collar work, the idea of forestry as real, hard work continued to dominate the field, including the academic subject (Johansson et al., 2018). However, these images are not immutable. As research has shown, masculinity and femininity can be fluid, also in disciplinary fields. This can be seen in fields such as dairy farming in Sweden where the mechanization of the field shifted it from a female to male domain or conversely in banking in both Germany and Finland (Tienari et al., 1998). It is also clear that what is masculinized (e.g., IT in Europe) in one place can be feminized in another (e.g., Malaysia see Lagesen, 2008).

In a study of emerging "green fields" such as environmental sciences and sustainability studies in the USA, Gelbgiser and Albert (2018) show how the green movement provided a direct incentive for change in HE. They argue that new and emerging "green fields" and degree programs are more likely to lack established stereotypes and norms, simultaneously careoriented and technical, or both humanistic and scientific, and therefore transcend traditional gender divisions and attract a broad distribution of students. They use their examples to show that, far from permanently settled, the distribution of students across fields is highly malleable and subject to change over time. The broader implication of this study is that changing the framing of academic fields can lead to different demographic outcomes and gendering.

Such a shift is clear in the gendered composition of environmental organizations in Sweden. Studies of a large environmental NGO (Arora-Jonsson \& Ågren, 2019) as well as an environmental authority (Arora-Jonsson \& Basnett Sijapati, 2018) showed how contrary to 
convention and the past, women outnumbered men. In these organizations, women were often engaged in what could be seen as "soft questions" of consumption or interdisciplinary questions related to biology, while the men worked with conservation and forestry, to some extent confirming both Gelbgiser and Albert's thesis of new orientations in environmentalism but also Barone's argument about gendered preferences of care and technology even within the field. What is masculine or feminine discipline is thus fluid and not set in stone, yet quite clearly also difficult to change.

We go on to study how this gendering might be linked to ideas about merit and how societal changes in thinking about the environment and the animal world might be triggering potential changes within the programs we study. We go on to analyze what that implies for gender-segregation.

\section{The myths of meritocracy and its antidotes}

There is no one definition of merit but merit is generally associated with talent, skill, intelligence, ability, and effort (Littler, 2017). Meritocracy, that is, a system built on the notion of merit, rests on two main premises - social mobility and that merit can be evaluated in a neutral and objective manner (Liu, 2011). Unraveling the myth of meritocracy Liu (2011) as well as others have demonstrated how merit is contingent and contextual. Variables such as ability, wealth, race and ethnicity, social class (Littler, 2017; Mijs, 2016), where you went to high school, the level of parental and family involvement (McNamee \& Miller, 2013; Warikoo \& Fuhr, 2014) and financial aid structures constrain participation in HE (Jonsson \& Rudolphi, 2011).

In Sweden, a governmental report (UHR, 2017:3) showed that HE is contingent on the parents being educated and that class (that often intersects with ethnic background and being non-white) and rural belonging tend to decrease participation in HE. Studies show that decisions on what counts as merit are in fact subjective. Homosociality, preferring sameness (Essed, 2004) as well as the inability to overcome prejudice and preferences (van den Brink \& Benschop, 2012; Wullum-Nielsen, 2016) influence academic recruitment and research funding.

While researchers have pointed to how protocols and guidelines can legitimize biased recruitment by lending them a spurious objectivity (van de Brink et al. 2010), scholars have also shown that establishing formal procedures are important in counteracting bias in recruitment processes (Rees, 2004; Reskin \& McBrier, 2000). Others (Pollock \& Hafner-Burton 2010; Ballington \& Karam, 2005), find support for hard binding instruments and the need for structural changes such as specification of parity laws and specified budgets to counter the failure of meritocracy. Affirmative action has been an important measure to address inequalities in the academy (Liu, 2011). Garces and Mickey-Pabello (2015) shows how a ban on affirmative action in the US significantly decreased the racial and ethnic student body in fields such as law, engineering, and the natural sciences and argues for innovative outreach and recruitment practices.

While such measures are important, subjective and everyday reproduction of gendered practices that reproduce inequalities are often more difficult to pin down. This requires close attention to the complex processes of gendering within a field of study and profession. In order to identify mechanisms that continue to reproduce gender-segregated programs within universities, we suggest a somewhat novel approach to merit. We regard merit, not only as criterion or practice that stops mattering when a student gains admission into university. Rather, we expand on the understanding of merit by bringing into view/discussion the informal and less 
visible aspects used to assign merit to students during the course of their studies, that influences their ability to act and take decisions that reproduce gender-segregation within the university and larger professional fields.

\section{Material and method}

We study two education programs - the Forest Science Program and the Veterinary Program at Swedish University of Agricultural Sciences (SLU). The material includes focus-groups (FGs, 8) with men and women, both separately and in mixed groups, semi-structured interviews with male and female teachers and administrators (14), three brief surveys with teachers and students in the two programs (see Table 2 of Appendix 1) and an analysis of university policy documents and websites. The focus-groups and interviews were recorded and transcribed.

The purpose of the different types of material and methods was to get an understanding of the everyday gendering practices in these programs and university attempts to address questions of gender segregation. The interviews and FGs were designed to understand the experiences of men and women to understand how social relations potentially constituted the phenomena we studied - in particular, segregation. In this, inspired by Dorothy Smith's (1987) approach of as the "everyday world as problematic," we sought to get an understanding of how gender was done in the everyday (West and Zimmerman 1987), and the relations that contributed to establishing social arrangements, especially participants' experiences excluded by dominant images of the programs. Following Bjerrum Nielsen and Davies (2016), we focus on classrooms as sites where gendered identities are formed but also where it is possible to challenge gendered discourses and practices. While gender is not the only axis of difference, the largely homogeneous groups of white, middle class men and women in both programs entailed that our focus was on men and women as groups (in some cases intersecting with identities as urban or rural) and their subjective understanding of gender-segregation and experiences of being part of the majority/minority. The three surveys (where we posed questions on how gender matter, or not, in education, see Appendix 1 (Table 2)) are used not as statistical material, but an indication of what gender equality questions were important for the respondents and what they believed that SLU needed to act upon. The surveys provided us with initial framing of the interviews and FGs.

We studied university documents and websites for official positions on gender equality and the measures that were considered appropriate to deal with segregation and discrimination. The documents included annual reports (AR) and university strategies (1994-2016), gender equality and the equal-opportunity strategies for Veterinary Sciences (2013-2016) and Forest Faculty (2015-2017) and plans for student recruitment. The websites were particularly illuminating because they targeted presumptive students. We paid special attention to the actors depicted in the websites, what they spoke about and the images that the university sought to project.

In order to analyze the material and especially policy texts, we studied how the "representation of the problem" (Bacchi, 2009) (here gender-segregation) in the polices and strategies is itself a productive activity. The way in which the texts interpret and speak about a problem create boundaries around their actions and also have lived effects, for example, in measures such as "girls-weekends" in forestry, images of what science is and mentoring programs to increase for women to the exclusion of what might be considered to be more structural or radical measures. 
Table 1 Gender segregation in the educational and professional fields

\begin{tabular}{llllll}
\hline & \multicolumn{2}{l}{ Faculty of Veterinary Sciences } & & \multicolumn{2}{c}{ Faculty of Forest Sciences } \\
\cline { 2 - 3 } & $\mathrm{F}$ & $\mathrm{M}$ & & $\mathrm{F}$ & $\mathrm{M}$ \\
\hline Students & $90 \%$ & $10 \%$ & $32 \%$ & $68 \%$ \\
Senior lectureship & $77 \%$ & $23 \%$ & & $31 \%$ & $69 \%$ \\
Professor & $47 \%$ & $53 \%$ & & $12 \%$ & $88 \%$ \\
Veterinarian & $78 \%$ & $22 \%$ & & \\
Professionals in large scale forestry & $15 \%$ & $85 \%$ & & & \\
Forestry entrepreneurs & $3 \%$ & $97 \%$ & & & \\
\hline
\end{tabular}

Statistics from SLU October 2019; statistics students 2017, SCB employment statistics, 2016

\section{Gender segregation at SLU}

More women than men study veterinary science, while more men than women study forestry. Table 1 displays a homogenous picture of a female dominated veterinary science and profession and a male dominated forestry sector.

The veterinary profession in Sweden underwent a transformation from being highly male dominated in the early to mid-1900s, to a doubling of women between 1955 and 1970. By the end of the 1970s, more women than men were studying veterinary science (Östensson, 2010). Conversely, the forestry sector is one of the most gender-segregated sectors in Sweden, where men have always dominated the field. The number of women in forestry education increased during the 1980s and 1990s, and since then numbers have fluctuated between $25 \%$ and $35 \%$. $^{3}$

Admission to the veterinary program is contingent on extremely high grades (according to admission statistics.se, the acceptance rate is ca 10\%). Conversely, grades needed for admission to the forestry program are low and most of the men and women who apply, get in, implying that neither men nor women with high grades tend to apply for the program. ${ }^{4}$ As one teacher remarked in an interview, "almost everyone gets in now." The number of women in the forestry program is close to the $40 \%$ required for what is regarded as a gender-equal workplace. However, as we can see (Table 1) this is clearly not reflected in employment in the sector, nor in the higher ranks in academia.

In late 2017, several green sectors were drawn into the \#metoo campaigns against sexual harassment. Sixteen female forest students wrote an open letter to the university and to the sector, demanding action (Johansson et al., 2018). Two blog posts from the Vice-Chancellors at SLU expressed concern at this and called for new momentum in work for gender equality (November 2017, January 2018). A code of conduct was developed at the Forestry Faculty as a tool for ensuring that harassments did not occur and an undergraduate course called "Gender competence in the forestry sector" was started in autumn 2019. The course is meant to "provide analytical tools to work on issues related to gender, inclusion and gender-equality at a practical level." Ahead, we go on to analyze the underlying tensions that led up to this moment.

\footnotetext{
${ }^{3}$ Compared with the rest of SLU: women were rewarded $71 \%$ of the degrees in 2019 (SLU statistics, retrieved 2020-03-10).

${ }_{5}^{4}$ In 2008, the grade needed was 16.06 , in 2016, 14.30.

5 www.slu.se/en/departments/forest-resource-management/sections/landscape-studies/genuskompetens/
} 


\section{Righting the balance: being gender-neutral versus changing gendered behavior}

Gender equality is an important aspect of policies and discourses on HE in Sweden. Institutions are obliged to address gender-segregation in their recruitment of new students (prop., 2016/17:50). Similar to most universities, SLU has run gender equality projects over the years in line with governmental directives. This has been prompted by the low number of women as professors and gender-segregation in education programs, primarily in the forestry and veterinary sciences (ARs 1994-2016).

The need to achieve gender balance in education programs has been a recurring worry (ARs, 1994-95, 2009). It is believed that gender balance would improve the study environment (AR 2004:18) and as an administrator explained in an interview, it prevented them from "missing half of the competence."

A women-only course (SLU 2001:12) was introduced by the forest faculty to enable women who lacked natural science criteria for admission to take a one-year introductory course to be eligible for the program. Sixteen places were reserved for women for the first 4 years. From 2005 however, the course opened up to both women and men. This was due to the other affirmative action program launched by the university in 2006 aimed at increasing the number of men in the veterinary program. This measure resulted in some men with lower grades than some number of women, being admitted to the program. The women took the university to court and won, and the university shut down the measure. As a result the forestry faculty had to open up their "girl track" measure for men as well in order not to discriminate against either sex.

Gender equality work changed to information campaigns, knowledge raising activities, and reaching out to presumptive students at university fairs. The need to attract more women to forestry continued through measures such as women-only weekends where potential students were introduced to the sector and for them to see that this was also something for them. ${ }^{6}$ SLU also tried to reach out to a broader group of students in relation to gender, socio-economic background, and ethnicity (SLU, 2016) through recorded interviews on their website. In one instance, two former female students emphasized the importance of ecosystem services, climate change, biodiversity, and the role of forests in the transformation to sustainable societies, showing the new and "green" and soft topics in the forestry program rather than the traditional masculine image of forest work associated with the program.

In a similar vein, information campaigns and rebranding efforts to attract men to the veterinary program were undertaken. In this case, information campaigns took a different route, one that highlighted "science" and toned down animal care aspects. An example is a picture on the program website that show students in white coats doing laboratory work. The heading reads: "Researcher or Epidemiologist?"7 The image expressed professionalism and objectivity (c.f. Oreskes, 1996) and hard science. In forestry, women needed to be convinced that forestry was also something for them, and be introduced gently to the program through a women-only activity. In the veterinary sciences, the approach was to invoke traditional science because it was assumed that men could not be expected to be interested in care (c.f Mykleburst 2020). Although the purpose of these

\footnotetext{
${ }^{6}$ www.slu.se/ew-kalender/2020/7/skogskurs-for-tjejer/

${ }^{7}$ www.slu.se/utbildning/program-kurser/program-pa-grundniva/veterinar/
} 
activities were to break gender-segregated education choices, ironically, they risked reinforcing gendered ideas of women associated with care and men with research and science, rather than challenging them-aspects that have been shown to lead to gendersegregation in the first place.

\section{Gender and merit in the everyday}

The two programs were fairly homogenous in their gendered and ethnic composition. In the focus groups and interviews with both teachers and students, forestry was described as dominated by a masculine culture of hunting, meat-eating, and focus on production and as white and rural. The veterinary program on the other hand was described by both students and teachers as female dominated, urban, white, and middle-class. In what follows, we go on to show how gendering practices in the everyday created different study conditions for women and men in the two programs so that merit, as defined by high grades and hard work, were not the only or main criteria for merit in the programs. This gendering played an important role in who the real forester and real veterinarian could be and what kind of "informal merit" was needed to fulfill this.

\section{(Re)producing norms: how your gender matters}

Hard work and effort are an important part of merit, along with talent, skill, intelligence, and ability (Littler, 2017). Interestingly enough, in both the programs, hard work carried negative connotations, at least as far as appearances were concerned. Some women experience this as keeping them in their place. In the forestry program, a woman observed, "you get bullied if you like to study." Another said, "I was also curious in the beginning but pretty soon you get it that if you ask a question they see me as an annoyance. One doesn't want to be that person, the one who asks questions then, so I kept quiet after a while."

In the veterinary program that required top grades to be admitted, hard work and ambition associated with women was seen as leading to stress and negatively affecting the study environment. As one female teacher said in an interview, "There are too many swots (girls) here." That this was a common phrase can be seen by one woman's angry retort in the survey in answer to the question of the issues that needed addressing in the program, "Yeah, we are told that we get all wired up, because that is what girls do. I keep being told... don't get so worked up."

In a focus-group, a male student suggested what he felt was the solution to the problem of too many stressed women,

"More gender diversified groups would decrease the stress. It might be controversial, but...... girls who come straight from high school and have always had the highest grades and always want to know it all...there are too many of them, and the stress in these groups is incredible..... I think the study environment would be much richer [with more men]. More exchange of different experiences and that...I have done military training for example..."

The solution to a stressful study environment, here seen as caused by overambitious women, was thus more men. The "effortless achiever" (Jackson \& Dempster, 2009; Nyström et al., 
2018) was preferred, and this position was exclusively for men. Women's hard work, an important criteria for formal merit, was interpreted as over ambition and in doing so, devalued.

A student wrote in the survey:

"Unfortunately, I think that men always are favored in the program. They are in a minority which gives them much more power than they would normally have. Especially the masculine men get a lot of attention"

Interestingly enough, the women in the forestry program as a minority there did not report on similar privileges. Instead, the gendering took another path where men defaulted but teachers did not intervene. A woman in a focus-group told us about a study-excursion where the teacher sent around a list to sign on the bus. When it came back, the teacher said: "I see 30 names on the list, but only 15 students in the bus." The woman pointed out that the missing students were all men but that their friends had signed for them. This incident was not followed up by the teacher, and according to the women in the focus-group, some men regularly covered up for each other this way.

Male students in both programs were seen as getting away with less effort. The informal merit of being a particular type of forester (being male, laid back, interested in production, hunting, meat-eating) had implications. A woman said,

“it's partly that you don't get invitations to parties, and other activities. But also, if you ask something at a lecture, you can hear a deep sigh from the back of the room if you are the wrong person asking the question... You need to hate wolfs!"

These norms were reinforced when applying for summer jobs in the forestry sector. According to one woman in a focus-group, men got offered jobs where they stood in for someone like the production manager because," They fulfill the norm, they have always employed that sort".

At the same time, women were expected to make the groups more congenial, "When there are only men, it is not so likeable, I think... a mixed group is nicer," said a male forestry student, in a way, echoing policy documents that believed that mixed groups would lead to better communication and atmosphere (AR 2004:18).

Thus, in the veterinary program, women were associated with stress and creating a difficult study environment, while in forestry their presence was seen as creating a nicer atmosphere. Their merit in such a case hinged on their sex rather than any other criteria. Further, formal merit of being a forestry student and getting good grades were not enough to get a job if you were a woman, suggesting that social mobility, a core aspect of meritocracy was failing.

There were other what might seem insignificant and yet important rituals in which norms were established such as that of fusknollor (fake-newbies). In what is meant to be a lighthearted attempt at humor, senior students pretend to be first year students and play stereotypical roles in the classroom as part of initiation rites. One woman told us that in her first year, there had been a man in the classroom who pretended to be homosexual, but turned out to be a fusknolla since being gay was humorous and counter-cultural. The norm for being a veterinary student, she felt, did not leave an opening if one was homosexual,

"It sent a really clear signal to me already the first week that, 'OK, you are really the odd one out here. I know some even thought that I was a 'fusknolla.' If you are only a little bit different, then you sort of become extreme and are pushed aside"

Norms about gender, race, and sexuality were reinforced through such incidents in the everyday that lay the parameters for those who did not fit in. 


\section{Gendering of physical prowess}

The need to be physically strong came through in both programs. This physical prowess was gendered male despite not necessarily being a characteristic needed for modern veterinary or forestry work and despite considerable evidence of women doing heavy labor.

The feminization of the veterinary profession over the years was explained to us by teachers as a combination of a number of factors - a shift from a profession concerned with production animals in rural areas (a traditionally male matter) to being an urban profession in clinics as well as the result of a larger societal change where there is an overall increase of women in HE.

Several students in the veterinary faculty echoed the worry that with too few men in the program, there would not be enough district veterinarians in the future. District veterinarians work large geographical areas and often with production animals such as cows, sheep, and pigs. In the surveys, some students believed that having a family and being a district veterinarian was difficult to reconcile and being a district veterinarian was not suitable for women. A student wrote, "Can women really, and do they really want to, work with all aspects of the veterinary profession? Or, will we end up with $80 \%$ of veterinarians working with pets? Are women the reason why the profession has such a low status and low salaries?"

Other students were annoyed by this. A female student said in a focus-group:

"On the whole, the profession is heavily influenced by a norm where women deal with cute small animals, and big strong men deal with large 'real' animals. This idea and the norm must be actively counteracted already during the program."

A woman who planned to become a district veterinarian felt that teachers did not think you would be interested in cows and such but in horses and smaller animals. This belief recurred in the subjective understanding of the field (c.f. Barone et al., 2019), reinforcing gendered divisions. A woman remarked,

"I assume that it is tough to work out in the districts...it seems as if you are often met with the attitude 'ok, here comes a little girl ..., they don't know anything, we will have to teach her ourselves...'."

Thoughts on women's suitability for the profession echo a newspaper article from 1959,

" a girl who intends to become a veterinarian has to be physically and mentally strong and perseverant, have a very strong interest in animals and medicine, preferably not have any plans of marriage and children (not for a long time at least), be prepared to not have her own home before the age of thirty (thirty five if she wants to work in the districts) and also that this home will not be in the part of the country where she would prefer to live" (Östgötakorrenspondenten).

Quite clearly, despite the immense mechanization and change in society, these ideas are hard to abandon. These were all the more tangible in the forestry program. Possible roles for women in the forestry sector were circumscribed by assumptions of physical strength and family. A woman related a story from class where a male student had commented on the suitability of women working in the forest with machines as according to him they would not be able to "loosen bolts and need to call in men to do that, making the whole enterprise very expensive."

Another woman had been told by a male student, 
"yeah...it might be difficult for women to have these jobs, they often mean you need to

be away and it can be difficult for women who have to take care of kids."

The mechanization of forestry as well as demands on new ways of managing forests has not necessarily changed thinking in relation to women. In line with this, the assumption that women were more interested in the "green" side of forestry (e.g., environmental and climate change aspects) than production came across clearly. In an all-male focus-group, students believed that,

"There are generally more men in the program...but, I think more women disappear in the green direction/path ..."

Students, both female and male, also related that those among them who studied "green" courses often did not belong to the core program, and that they often kept to themselves, or moved to other campuses to take courses. Students told us that this group of students included not only women but also men who did not fit the norm, e.g., from the cities or with a nonforestry background. This path was nick-named "fruit and greens," a derogatory label for being interested in environmental questions.

As Gelbgiser and Albert (2018) suggest, outside pressure from environmental movements can be seen in the way that the forest program is beginning to advertise itself and run new courses. However, this was derided by many men who saw that as outside of real forestry. ${ }^{8}$ Nonetheless, new "green" studies decried by traditional forestry may be bringing needed tensions into the forestry program, especially as the make-up of environmental agencies seem to suggest (c.f. Arora-Jonsson \& Basnett Sijapati, 2018; Arora-Jonsson \& Ågren, 2019).

The gendering of the two programs that surfaces above relates in both cases to the need for physical strength (gendered male) and to family responsibilities (gendered female). Physical strength in both programs is considered an "informal merit." As is being someone not having family responsibilities. Both were associated with being male. The mechanization and academization of forestry and the change of the veterinary profession from mainly rural and farming animals to urban clinics, pets, or office work have reduced the need for physical strength and also increased the possibilities to combine family and work for both men and women. Despite this, these arguments recur in the interviews as descriptions of the real forester or veterinarian. Further, in forestry, the addition of women is seen as complementing the "core," that is, production forestry with environmentally friendly aspects needed today. Thus, fairly evident is the gendering that accompanies the notion of merit in relation to both.

\section{Discussion}

Scholars have called attention to how merit is contingent on the social context (Littler, 2017; Mijs, 2016). Turning to our material, we have delved on a very different aspect in relation to the idea of academic meritocracy - informal merits, where actual formal merit is often second to sex. As we see from the discussion above, formal merit in terms of what grades one has seemed to play a much smaller role once the applicants were in the organization, especially in relation to the understanding of who a real "forester" or "veterinarian" were meant to be. Thus, we propose that we need to think about merit as a dynamic category - that can change once

\footnotetext{
${ }^{8}$ To put this in context - the debates between environmentalists and proponents of the forest industry have become extremely acrimonious in recent years.
} 
students join their programs - and that different understandings of merit contend with each other in the course of the programs. Such an understanding of merit, we argue, is central to confronting persistent gender-segregation despite university attempts to right the balance between women and men in natural science programs.

As Barone et al. (2019) write, subjective beliefs concerning the chances to succeed in different fields rather than their perceived profitability tend to contribute to gender differences across various academic fields. In this paper, we have pointed to some of these experiences specially of women within the academy that contribute to shaping the larger field and that influence the subjective beliefs of prospective applicants.

In both programs, being male gave certain privileges. These included not having to work as hard but being the right type (forestry) or by virtue of being one of very few men in the program and getting away with a more relaxed attitude (veterinary). Men were expected to, by their presence, create less stressful environments and to raise the status of the profession in the veterinary program. In both programs, men were connected to the production side of the profession, with farm animals and with the forest industry, while women as well as the nonnormative men (in the case of forestry) were seen as being connected to the "softer" parts such as pets and environmental questions ("fruit and greens"). These sides of the professions came across as less valued within the programs. However, keeping in mind work by Gelbgiser and Albert (2018), these paths also have the potential to change the programs themselves. How that continues to be gendered is, of course, a question for further investigation.

For the women in the veterinary program, for instance, once they did get in and despite being in a majority for a long time, they were still seen as transgressive because their presence seemed to suggest a problem for district work. It was assumed that more men would automatically guarantee more veterinarians in that field. ${ }^{9}$ While merit was needed to get in, once in, the constant wish for more male students made it appear to the women that formal merit did not count as much as their sex.

Women related stories about being met with reluctance in the professions and of whether they were "up to it," which was not the case when it came to the men. Everyday practices such as "fusknollor" or the fact that teachers did not admonish men who were clearly evading studies enabled a reproduction of the system. Male homosociality (Essed, 2004) in the forestry program, for instance, especially in relation to getting summer jobs, may be seen as a significant barrier to women's advancement in the sector.

Furthermore, many women felt undervalued by the unspoken assumptions about their inabilities to carry out the profession due to family responsibilities or lack of physical strength or for their education paths within the programs. Physical strength that was directly correlated with men was an informal merit in both, regardless of how strong individual men or women were or whether it was even needed. This was exacerbated by sexual harassment in the forestry program. What Oreskes (1996) had called the heroic field scientist conjuring a vision of a man of physical strength who is willing to sacrifice the emotional attachments of normal life for the sake of his questioning remains quite clearly gendered male in these two fields. Contrary to the image presented by Oreskes however, of willing to sacrifice your own life, the image of the students here prioritized not being too ambitious or studying too hard as women were seen as prone to doing. In the veterinary program, it was seen as leading to stress and a poor study

\footnotetext{
${ }^{9}$ This is regardless of the larger question of the shrinking base of agriculture, the disappearance of farming, and flight from rural areas to the cities that quite obviously affects the profession as a whole for young people looking for future avenues and jobs.
} 
environment, while in the forestry program "trying to get away" with as little as possible was a positive sign, and the women felt their focus on their studies created irritation.

The material indicates that these experiences need to be taken seriously, not only that of women but also that of men, especially those who do not necessarily align themselves with the norms but felt unable to challenge them. Formal merit is an important part of academic practice, and should continue to be so, but, as we have shown here, when informal merits take over, we need to develop ways of addressing them.

In the veterinary program, the inclusion of men to the program may be seen as counteracting merit if the men taken in did not have similar grades. In this case, male aspirants were not necessarily at a disadvantage due to their sex but in fact their grades (or merit). In the forestry program, where grades were low in general, this was different. Anyone who wanted to get in, did get in. Programs such as the women-only entry course in such a case could be useful in counteracting the masculine coded program. Thus, formalized procedures proved to benefit women and merited men (Pollock \& HafnerBurton 2010). The affirmative action in the veterinary program and the girl track in the forestry did increase the number of students and yet it was seen as counteracting the notion of merit in both cases. The attention to context was ignored and the idea abandoned also in the forestry program, thus taking a step back.

However, affirmative action, while important, has alone not been enough to confront the culturalist assumptions inherent in the academy and professional fields - as we show here not only in the male dominated field of forestry but also the veterinary program. In fact, the domination of women in veterinary science seemed to have further glorified the image of the physically strong male veterinary needed to work in rural areas. The university's attempt at "gender-neutralizing" the program in effect meant appealing to a masculine norm.

So, what can work? As we have argued here, there is a need for contextual and situated understanding of the gendering and practices that affirm informal merit in classrooms, to address continual segregation both in HE and the professional field. This entails that reform measures need to be situated. For example, while affirmative action in forestry could be justified due to discrimination in the field, it might not be in the veterinary school because the segregation originated due to different sources. Scholars have suggested doing away with the notion of meritocracy (as ideas built on equality of opportunity) altogether to be replaced by equality of outcome (Littler, 2017). Based on our work, we suggest a more situated and reflexive approach to merit where close attention to the construction of merit actually entails in a particular context.

Feminists studying the entry of women in politics have argued that what is needed for equality change are also institutional and representational changes such as the specification of women's budgets and the specification of parity laws (Ballington \& Karam, 2005). This has been reinforced by others who show how the institution of hard incentives is important in bringing about change (Pollack \& Hafner-Burton, 2010). Notably, changes in discourse to change the way in which women are referred to, how their participation is evaluated and sought after, partnerships with men are formed, and their efforts are assessed are extremely important (Ballington \& Karam, 2005). As the presence of a large number of women in environmental organizations (Arora-Jonsson \& Ågren, 2019) and the work of Gelbgiser and Albert (2018) indicates, changing the framing of academic fields to a green approach can lead to different demographic outcomes. Perhaps the time of the "fruits and greens" to change the subject is at hand. 


\section{Appendix 1}

Table 2 Empirical material

\begin{tabular}{|c|c|c|c|c|}
\hline Activity & $\begin{array}{l}\text { How } \\
\text { many }\end{array}$ & With who & $\begin{array}{l}\text { How } \\
\text { long }\end{array}$ & Examples of questions asked \\
\hline Focus group & 8 & $\begin{array}{l}3 \text { women forestry students aged } \\
20-30 \text { yrs. }(2018-19) \\
1 \text { men forestry students aged } \\
20-30 \text { yrs. }(2019) \\
3 \text { mixed women/men } \\
\text { vet-students aged } 20-30 \text { yrs. } \\
\text { (2011) } \\
1 \text { mixed women/men teachers } \\
30-60 \text { yrs. }(2011)\end{array}$ & $2-3 \mathrm{~h}$ & $\begin{array}{l}\text { Describe your education with regard to } \\
\text { gender equality. } \\
\text { Describe the norms at the education } \\
\text { programs and tell us more about if and } \\
\text { how they affect the study environment. } \\
\text { How would you describe a typical student in } \\
\text { your program? } \\
\text { Here we also asked questions about } \\
\text { discrimination and harassment in the } \\
\text { education programs. }\end{array}$ \\
\hline $\begin{array}{l}\text { Semi-structured } \\
\text { interviews }\end{array}$ & 14 & $\begin{array}{l}\text { Teachers/administrators } \\
30-65 \text { yrs., (2012, } \\
\text { 2018-19). Women and men. }\end{array}$ & $1-2 \mathrm{~h}$ & $\begin{array}{l}\text { Same as above and also: } \\
\text { When/if you bring up gender with your } \\
\text { colleagues and students, what reactions } \\
\text { do you meet? }\end{array}$ \\
\hline Surveys & 3 & $\begin{array}{l}\text { Vet-students }(900 \\
\text { respondents } / 82 \text { responses }) \\
(2011) \\
\text { Teachers }(80 \text { respondents } / 27 \\
\text { responses) }(2011) \\
\text { Students }(2092 \\
\text { respondents } / 214 \text { responses }) \\
\text { (2019) }\end{array}$ & & $\begin{array}{l}\text { What are the gender equality questions of } \\
\text { importance at SLU? } \\
\text { Does gender matter in your } \\
\text { education/teaching? Yes/no. Describe } \\
\text { when/how. } \\
\text { From the survey we only used the free text } \\
\text { answers. No statistical analysis was made. }\end{array}$ \\
\hline
\end{tabular}

Funding Open access funding provided by Swedish University of Agricultural Sciences.

Open Access This article is licensed under a Creative Commons Attribution 4.0 International License, which permits use, sharing, adaptation, distribution and reproduction in any medium or format, as long as you give appropriate credit to the original author(s) and the source, provide a link to the Creative Commons licence, and indicate if changes were made. The images or other third party material in this article are included in the article's Creative Commons licence, unless indicated otherwise in a credit line to the material. If material is not included in the article's Creative Commons licence and your intended use is not permitted by statutory regulation or exceeds the permitted use, you will need to obtain permission directly from the copyright holder. To view a copy of this licence, visit http://creativecommons.org/licenses/by/4.0/.

\section{References}

Admission statistics.se Retrieved 2021-02-11 http://antagningsstatistik.se/en/course/Veterinary_Medicine programme/77108

Arora-Jonsson, S., \& Ågren, M. (2019). Bringing diversity to nature: Politicizing gender, race and class in environmental organizations? Environment and Planning E: Nature and Space. https://oi.org/10.1177/ 2514848619866381

Arora-Jonsson, S., \& Basnett Sijapati, B. (2018). Disciplining gender in environmental organizations: The texts and practices of gender mainstreaming. Gender, Work and Organization, 25(3), 309-325.

Bacchi, C. (2009). Analysing policy: What's the problem represented to be? Frenchs Forest.

Ballington, J., \& Karam, A. (2005). Women in parliament: Beyond numbers. IDEA. 
Barone, C., Schizzerotto, A., Assirelli, G., \& Abbiati, G. (2019). Nudging gender desegregation: A field experiment on the causal effect of information barriers on gender inequalities in higher education. European Societies, 21(3), 356-377.

Barone, C. (2011). Some things never change: Gender segregation in higher education across eight nations and three decades. Sociology of Education, 84(2), 157-176.

Barone, C., \& Ortiz, L. (2011). Overeducation among European University graduates: A comparative analysis of its incidence and the importance of higher education differentiation. Higher Education, 61, 325-337.

Bjerrum Nielsen, H. \& Davies, B. (2016) Formation of gendered identities in the classroom. Wortham et al. (eds.), Discourse and education, encyclopedia of language and education. Springer International Publishing Switzerland.

Brandth, B., \& Haugen, M. S. (2005). Doing rural masculinity - From logging to outfield tourism. Journal of Gender Studies, 14(1), 13-22.

Crozier, G., Reay, D., \& Clayton, J. (2009). Different strokes for different folks: Diverse students in diverse institutions. Research Papers in Education, 23(2), 167-177.

Dryler, H. (1998). Parental role models, gender and educational choice. British Journal of Sociology, 49(3), 375398.

Essed, P. (2004). Cloning amongst professors. Normative and imagined homogeneities. Nora, 12(2), $113-122$.

Garces, L., \& Mickey-Pabello, D. (2015). Racial diversity in the medical profession: The impact of affirmative action bans on underrepresented student of color matriculation in medical schools. Higher Education, 86(2), 264-294.

Gelbgiser, D., \& Albert, K. (2018). Green for all? Gender segregation and green fields of study in American higher education. Social Problems, 65, 564-583.

Gonsalves, A. J., Danielsson, A., \& Pettersson, H. (2016). Masculinities and experimental practices in physics: The view from three case studies. Phys. Rev. Phys. Educ. Res., 12, 020120.

Ingram, N., \& Allen, K. (2019). 'Talent spotting' or 'social magic'? Inequality, cultural sorting and constructions of the ideal graduate in elite professions. The Sociological Review, 67(3), 723-740.

Ingram, N. (2011). Within school and beyond the gate: The complexities of being educationally successful and working class. Sociology, 45(2), 287-302.

Irvine, L., \& Vermilya, J. R. (2010). Gender work in a feminized profession: The case of veterinary medicine. Gender \& Society, 24(1), 56-82.

Jackson, C., \& Dempster, S. (2009). 'I sat back on my computer...with a bottle of whiskey next to me': Constructing 'cool' masculinity through 'effortless' achievement in secondary and higher education. Journal of Gender Studies, 18(4), 341-356.

Johansson, M., Johansson, K., \& Andersson, E. (2018). \#Metoo in the Swedish forest sector: Testimonies from harassed women on sexualised forms of male control. Scandinavian Journal of Forest Research, 33(5), 419425.

Jonsson, J., \& Rudolphi, F. (2011). Weak performance - Strong determination. School achievement and educational choice among ethnic minority students in Sweden. European Sociological Review, 27, 487-508.

Lagesen, V. (2008). A Cyberfeminist utopia? Perceptions of gender and computer science among Malaysian women computer science students and faculty. Science, Technology and Human Values, 23(1), 1-23.

Littler, J. (2017). Against meritocracy: Culture, power and myths of mobility. Routledge.

Liu, A. (2011). Unraveling the myth of meritocracy within the context of US higher education. Higher Education, 62, 383-397.

McNamee, S., \& Miller, R. (2013). The meritocracy myth. Rowman and Littlefield Publishers.

Mastekaasa A. \& Smeby, J. (2005). Educational choice and persistence in male and female-dominated fields. Working paper, 3, Oslo University college, Centre for study of professions.

Mijs, J. (2016). The unfulfillable promise of meritocracy: Three lessons and their implications for justice. Education Soc Just Res., 29, 14-34.

Mincer, J. \& Polachek, S. (1974). Family investments in human capital: Earnings of women, Journal of Political Economy 82, 2:2, S76-S108.

Myklebust, R. B. (2020). Gendered repertoires in nursing: New concpetualizations of educational gender segregation. Gender and Education. https://doi.org/10.1080/09540253.2020.1765993.

Nahai, R. (2013). Is meritocracy fair? A qualitative case study of admissions at the University of Oxford. Oxford Review of Education, 39(5), 681-701.

Nyström, A.-S., Jackson, C., \& Salminen-Karlsson, M. (2018). What counts as success? Constructions of achievement in prestigious higher education programmes. Research Papers in Education, 34(4), 465-482.

Oreskes, N. (1996). Objectivity or heroism? On the invisibility of women in science. Osiris, History of Science Society, 11, 87-113.

Östensson, K. (2010). Från Manligt till Kvinnligt i Veterinär - yrke i förvandling. Sveriges Veterinärförbund 150 år. Sveriges veterinärförbund. 
Östgötacorrespondenten, Är veterinäryrket lämpligt för kvinnor? Birgitta Lagerman, 1959.

Pollack, M. A., \& Hafner-Burton, E. M. (2010). Mainstreaming international governance: The environment, gender, and IO performance in the European Union. Review of International Organizations, 5(3), 285-313.

Prop. (2016)/17:50 Higher Education Act of Sweden, https://www.esv.se/statsliggaren/regleringsbrev/?RBID= 20296

Puwar, N. (2004). Space invaders: Race, gender and bodies out of place. Berg.

Rees, T. (2004). Measuring excellence in scientific research: The UK Research Assessment Exercise, in Gender and Excellence in the Making. EUR 21222. Brussels: DG-research, European Commission.

Reskin, B. F., \& McBrier, D. (2000). Why not ascription? Organizations' employment of male and female managers. American Sociological Review, 65(2), 210-233.

Sandström, U., \& Wold, A. (2010). Hans excellens: om miljardsatsningarna på starka forskningsmiljöer. Delegationen för jämställdhet i högskolan.

SCB employment statistics. (2016). Statistics Sweden.

She Figures. (2018).

SLU. (1994/95-2016). Annual Reports.

SLU, Equal-Opportunities Plan Faculty for Veterinary Sciences. (2013-2016). SLU.

SLU, Equal-Opportunities Plan Forest Faculty. (2015-2017). SLU.

SLU. (2016). Inriktningsdokument för utbildning på grund- och avancerad nivå 2017-2020.

Smith, D (1987). The everyday world as problematic. A feminist sociology. Northeastern University Press, Boston.

SOU. (2009). Flickor och pojkar i skolan: hur jämställt är det? Delbetänkande från Delegationen för jämställdhet i skolan, 2009:64.

SOU. (2011). Svart på vitt - om jämställdhet i akademin. Betänkande av Delegationen för jämställdhet i högskolan, Stockholm: Delegationen för jämställdhet i högskolan.

Tienari, J., Quack, S. \& Theobald, H. (1998). Organizational reforms and gender: Feminization of middle management in Finnish and German banking. Discussion Papers, Research Unit: Organization and Employment FS I 98-105, WZB Berlin Social Science Center.

UHR. (2017). Swedish Council for Higher Education. National statistics for admissions. Retrieved 2019-11-20.

van den Brink, M., Benschop, Y., \& Jansen, W. (2010). Transparency in academic recruitment: A problematic tool for gender equality? Organization Studies, 31(11), 1459-1483.

van den Brink, M., \& Benschop, Y. (2012). Gender practices in the construction of academic excellence: Sheep with five legs. Organization, 19(4), 507-524.

Warikoo, N. K. (2016). The diversity bargain. The University of Chicago Press.

Warikoo, N. K., \& Fuhr, C. (2014). Legitimating status: Perceptions of meritocracy and inequality among undergraduates at an elite British university. British Educational Research Journal, 40, 699-717.

Wennerås, C., \& Wold, A. (1997). Nepotism and sexism in peer-review. Nature, 387, 341-343.

Wullum-Nielsen, M. (2016). Limits to meritocracy? Gender in academic recruitment and promotion processes. Science and Public Policy, 43(3), 386-399.

Publisher's note Springer Nature remains neutral with regard to jurisdictional claims in published maps and institutional affiliations. 